\title{
㱙青路面结构内部的力学响应特征及分析
}

王旭东, 周兴业 ${ }^{*}$, 关伟，肖倩

*联系人, E-mail: zhouxingye1982@163.com

2020-03-05 收稿, 2020-04-21 修回, 2020-04-26 接受, 2020-04-27 网络版发表 国家重点研发计划(2018YFB1600103)资助

摘要 为了揭示沥青路面结构内部的力学响应特征及变化规律, 为研发适合我国国情和公路建设特点的沥青路面 结构设计方法提供可靠的实测数据, 依托我国足尺路面试验环道RIOHTrack, 开展了沥青路面结构内部应力应变等 力学响应的持续跟踪观测, 分析了不同影响因素下力学响应行为的变化规律. 结果表明, 励青路面结构内部的力学 响应具有明显的温度依赖性和荷载依赖性, 且随着温度、荷载的变化呈现显著的非线性变化特征, 并表现出以年 为周期的交替波动变化; 温度变化除引起力学响应数值的增减以外, 还会引起某些位置处力学响应方向的改变, 出 现压缩到拉伸或者拉伸到压缩的状态转换, 应变与温度的关系曲线存在拉伸-压缩转换点和应变 0 值线, 出现压缩拉伸转换的深度位于24 36 cm之间，随着温度的升高，压缩-拉伸转换的位置会渐渐背离路表而向下移动; 沥青层 层底应力、应变响应随着荷载水平的增加而显著增大, 并表现出明显的非线性变化趋势, 尤其是在高温、重载时 非线性现象更加明显. 研究成果可为完善励青路面设计及分析方法提供一定的数据支撑.

关键词力学响应, 励青路面, 应力, 应变, 路面设计

在沥青路面服役性能分析、结构力学计算中，路 面结构内部的应力、应变状态是一个关键性的技术指 标. 在二十世纪五六十年代, 国际上一些专家通过室内 模型试验、现场的弯沉检测以及弹性层状体系理论的 力学分析, 间接推导得到沥青路面结构内部的应力、 应变数值. 以此为基础，在20世纪60 80年代的20多年 间，世界各国先后建立了沥青路面“力学-经验法”的设 计体系, 用于指导沥青路面的设计与建造. 然而, 在实 际荷载与环境耦合作用下, 沥青路面结构的力学响应 规律如何, 与理论上的路面力学分析结论是否一致、 存在多大差异, 始终是沥青路面技术体系中的重大理 论问题，也是长寿命沥青路面设计体系研发中的关键 瓶颈问题.

为了研究实体路面结构内部的力学响应行为, 国
外研究人员主要依托实体工程试验路和足尺环道等手 段 ${ }^{[1]}$ 开展相关工作. 由于需要借助应变计、应力计、位 移计等传感器技术获取路面结构内部的力学响应数据, 直到 20 世纪 90 年代中期, 国际上才陆续开展系统性的 路面结构实测力学响应数据的跟踪观测. 1994年, 美国 明尼苏达州试验路 ${ }^{[2,3]}$ 投人使用，在 40 个试验段的结构 内部埋设了17类4500多个传感器, 测试路基路面结构 内的水平和垂直方向的应变、含水率和温度等信息, 为分析比较美国寒冷地区不同路面结构的服役性能提 供了重要的数据支撑. 1996年, 美国西部环道 ${ }^{[4,5]}$ 开始加 载运行, 由于其研究方向主要集中在基于使用性能的 热拌沥青混合料设计规范上，很少关注路面结构力学 响应问题, 仅在部分试验段埋设了少量传感器, 所采集 到的力学响应数据较少, 不具参考意义. 2000年, 美国 
国家沥青研究中心(National Center for Asphalt Technology, NCAT) 试验环道 ${ }^{[6-9]}$ 开始第一期加载试验，该期修 建的46个试验段全部采用柔性基层沥青路面结构，每 个试验段的结构内部均安装了应力应变传感器, 用于 分析路面在受到行车荷载作用时的应力应变响应规律, 校正路面设计模型的参数，为美国力学经验法设计指 南的诞生作出了重要贡献. 此外, 法国交通研究所环 道 ${ }^{[10]}$ 、西班牙公共设施研究试验中心足尺环道 ${ }^{[11]}$ 和日 本道路工程研究所试验环道 ${ }^{[1]}$ 等, 也开展了实际路面结 构力学响应的观测, 为各国沥青路面结构设计方法的 研究提供了必要的基础数据.

从 20 世纪 90 年代末开始，我国依托室外大型加速 加载设备开展路面结构内部应力、应变响应状态的数 据采集 ${ }^{[1,12]}$ ，但由于简化了路面结构、数据采集周期 短、力学响应信息采集不完整等, 导致我国在这方面 的研究滞后于世界路面技术先进国家，成为我国沥青 路面技术发展的短板. 例如, 在2017版《公路沥青路面 设计规范》修订时, 大量采用了美国NCAT试验环道的 观测数据 ${ }^{[13]}$. 然而, 由于NCAT环道使用的柔性基层沥 青路面与我国常用的半刚性基层沥青路面有较大差异, 导致结构内部的力学响应特征和演化规律存在较大的 不同. 因此, 自主开展我国沥青路面结构力学响应状态 的观测与研究对推动我国沥青路面技术的创新发展是 十分必要的.

2015年底，由交通运输部公路科学研究院负责建 成了国内第一条足尺路面试验环道(Research Institute of Highway MOT Track, RIOHTrack ${ }^{[14]}$. 在环道主试 验路段铺设的19种不同形式的沥青路面结构中埋设了 近 1200 个动态应力、应变传感器, 实时采集荷载与环 境耦合作用下沥青路面结构内部的力学响应状态. 至 今已开展了持续 3 年的采集工作, 积累了较为完整的不
同路面结构内部的应力、应变响应信息. 为此, 本文依 托RIOHTrack的力学监测数据, 研究了沥青路面结构内 部应力、应变响应随温度、荷载、结构深度分布的变 化特征, 分析了温度对力学响应数值和受力方向的影 响规律, 建立了应力、应变与温度之间的关系模型, 揭 示了力学响应的荷载依赖性和非线性, 为完善沥青路 面设计及分析方法提供了可靠的数据支撑.

\section{1 沥青路面结构内部的力学响应观测}

为了研究沥青路面结构内部的力学响应特征，选 择RIOHTrack主试验路段的半刚性基层长寿命路面结 构STR1以及全厚式长寿命沥青路面结构STR19作为研 究对象, 通过在结构内部埋设应力、应变传感器的方 法, 观测其力学响应.

\section{1 应力、应变传感器的布设}

RIOHTrack沥青混凝土结构层的水平应变采用 TML公司的“工字型”KM-100 HAS动态沥青应变计(图 1(a))进行观测，半刚性材料层水平应变采用TML公司 的KM-100A动态混凝土应变计(图1(b))进行观测, 各结 构层的坚向应力 $\sigma_{z}$ 采用Sisgeo公司的P252A型液压土压 力计进行观测，结构层内部温度采用锦州精微仪表有 限公司的PT100铂电阻温度传感器进行观测 ${ }^{[1]}$. 这些传 感器布设于每层路面结构层的层底位置处, 每层观测 水平应变的应变计采用矩阵形式设计：在正方形四个 角上沿行车方向和垂直行车方向各埋设一个应变计 ${ }^{[1]}$ (图2), 沿行车方向埋设的称为纵向应变计, 记为 $\varepsilon_{y}$, 垂直 行车方向埋设的称为横向应变计, 记为 $\varepsilon_{x}$. 考虑到 RIOHTrack每种结构的试验段落仅有 $50 \mathrm{~m}$ ，故选择每 个段落的中间位置埋设传感器、安装数据采集模块. 由于每种结构需要埋设的传感器数量较多且需要各层
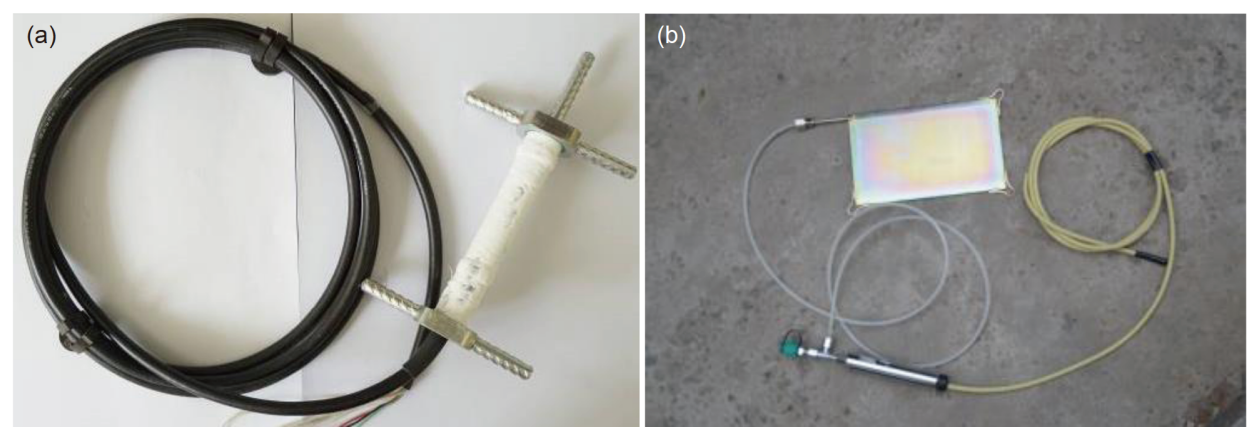

图 1 (网络版彩色)应变/应力传感器. (a) 沥青应变计; (b) 土压力计

Figure 1 (Color online) Strain/stress sensor. (a) Asphalt strain sensor; (b) soil stress sensor 


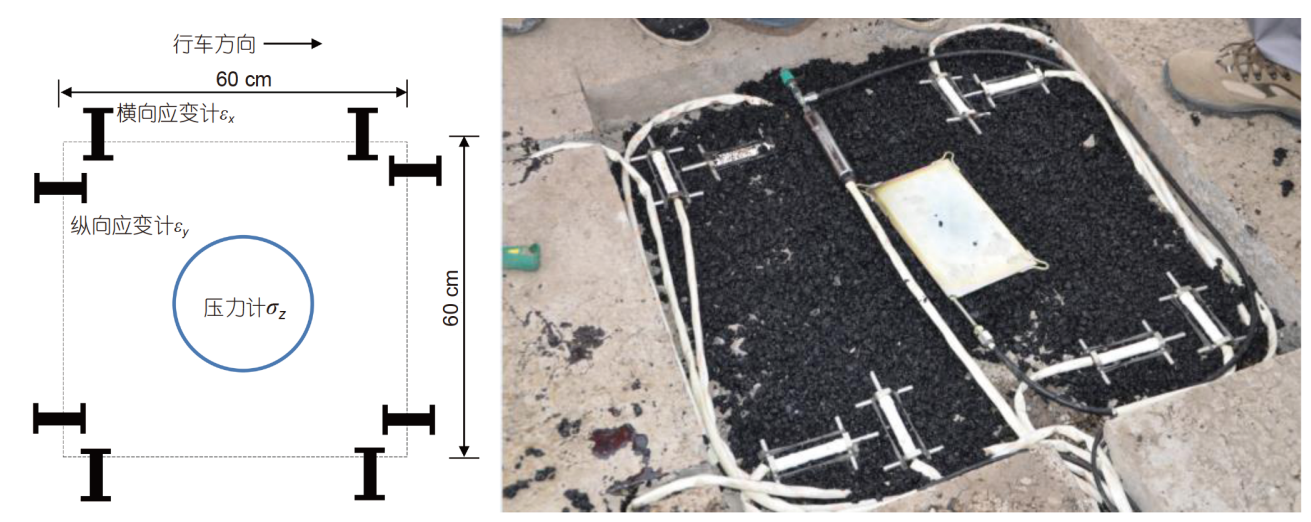

图 2 (网络版彩色)应变计和压力计布设示意图

Figure 2 (Color online) Layout diagram of strain sensor and pressure sensor

上下位置对应, 各传感器之间的距离较小、位置集 中、引线较多，更适合使用图2所示的“后埋法”进行埋 设. 为了解决“后埋法”传感器附近结构层整体性较 弱、压实效果不良的问题，根据开槽取板处的体积、 该结构层施工当天抽检的最大理论密度和现场压实度 三个指标计算需要回填沥青混合料的质量，并将全部 沥青混合料回填至开槽处，再利用压路机将其碾压平 整，以保证传感器附近结构层的压实度和整体性. 同 时, 为了提高存活率, 在埋设过程中全程监测传感器的 响应波形,一旦出现失效的情况, 便将其当场挖出, 更 换新的传感器以后, 再重新埋设.

\section{2 路面结构形式}

在本文研究的两种结构中, STR1由两层厚度为 $20 \mathrm{~cm}$ 的水泥稳定土底基层 CS、两层厚度为 $20 \mathrm{~cm}$ 的水 泥稳定碎石基层 $\mathrm{CBG} 25$ 、一层厚度为 $8 \mathrm{~cm}$ 的低标号沥 青混凝土下面层 $\mathrm{AC} 20(\mathrm{AH}-30)$ 以及一层厚度为 $4 \mathrm{~cm}$ 的 改性沥青混凝土表面层AC13(SBS)组成, 路面结构总厚 度为 $92 \mathrm{~cm}$; STR 19 由一层厚度为 $20 \mathrm{~cm}$ 的水泥稳定碎石 底基层 $\mathrm{CBG} 25$ 、三层厚度为 $12 \mathrm{~cm}$ 的低标号沥青混凝 土基层 $\mathrm{AC} 25(\mathrm{AH}-30)$ 、一层厚度为 $8 \mathrm{~cm}$ 的低标号沥青 混凝土下面层 $\mathrm{AC} 20(\mathrm{AH}-30)$ 以及一层厚度为 $4 \mathrm{~cm}$ 的表 面层SMA13(SBS)组成, 路面结构总厚度为 $68 \mathrm{~cm}^{[15]}$.

\section{3 力学响应观测试验}

采用落锤式弯沉仪(falling weight deflectometer, FWD)作为试验荷载, 同步采集施加FWD落锤荷载时 STR1和STR19两种路面结构内部的应力、应变实时响 应数据. FWD仪器的承载板作用位置位于图 2 中土压力 计的正上方, 试验荷载水平共 4 级, 分别为 $5 、 7 、$
9、 $11 \mathrm{t}$. 每级荷载进行3次平行试验, 取它们的均值作 为试验结果, 当平行性较差时, 重新进行试验. 2017年1 月 2018年6月，每半个月采集一次FWD荷载作用下的 结构内部力学响应；2018年7月 2020年2月，每个月采 集一次. 图3为某次FWD检测时, 荷载水平为 $5 \mathrm{t}$ 情况下, STR19结构层内部 $h=12 \mathrm{~cm}$ 位置处应力响应波形的时 程曲线示意图. 可以看出, 时程曲线存在基线、波峰和 波谷三个特征参数, 选择波峰与基线的差值(即波峰值) 进行应力、应变响应的分析，未取用波谷值和波峰波 谷相对值.

\section{2 力学响应观测结果与分析}

如前所述，准确获取沥青路面结构内部力学响应 特征, 揭示路面真实服役行为的演化过程和性能演变 机理，是建立沥青路面设计方法的核心问题. 我们知 道, 沥青路面在服役过程中, 受温度、荷载等外部环境 因素的影响，不同路面结构会表现出差异化的服役行 为. 而且, 随着温度、荷载等沿深度方向的梯度分布,

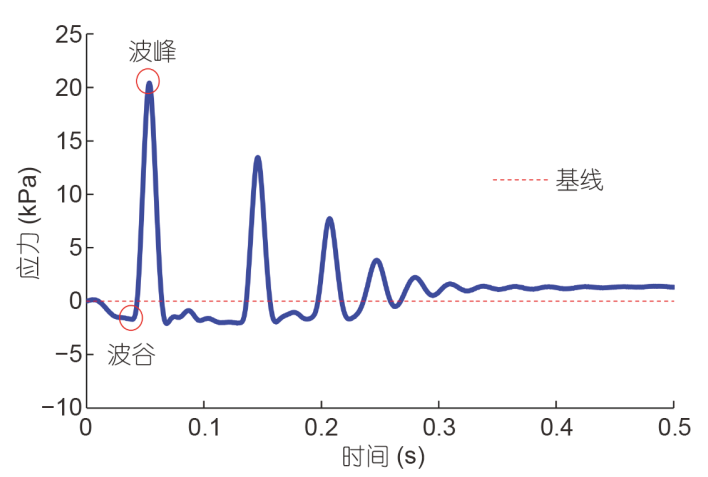

图 3 (网络版彩色)应力时程曲线

Figure 3 (Color online) Time-history curves of stress 
各结构层中的力学响应状态也会随位置不同而发生变 化, 使得结构受力状态变得更为复杂, 这些通过理论计 算很难发现，只有通过对实体路面结构受力状态的实 测与分析, 才能获得真实响应数据. 在此基础上, 当开 展沥青路面结构分析时, 根据观测得到的路面结构的 实际响应特征，建立与之对应的计算体系和分析理论， 才能保证力学分析方法的合理性和可靠性. 因此, 为了 深人研究不同因素下沥青路面结构内部的力学响应, 我们主要针对沥青路面力学响应在年循环周期内的温 度、荷载、深度等因素影响下的实际响应特征和变化 规律, 为建立适合我国国情和公路建设特点的新一代 沥青路面设计及分析方法提供基础数据.

\section{1 年周期内力学响应特征的变化规律}

一般情况下, 越靠近路表, 路面结构内部的力学响 应数值越大，也越容易受到温度、荷载等外部因素的 影响, 因此在研究年周期内力学响应特征的变化规律
时，选择RIOHTrack主试验路段的全厚式长寿命沥青 路面结构STR 19 内部深度 $h$ 为 $12 \mathrm{~cm}$ 处的沥青层层底应 力、应变进行研究. 为了与国际上通用的结构受力方 向表达习惯相统一, 将应力实测值为正值、应变实测 值为负值时的力学响应状态定义为压缩状态, 分别对 应于压应力、压应变; 反之, 将应力实测值为负值、应 变实测值为正值时的力学响应状态定义为拉伸状态, 分别对应于拉应力、拉应变.

图4为2017 2019年间FWD荷载为5 t时, RIOHTrack主试验结构STR19内部深度为 $12 \mathrm{~cm}$ 处沥青层层 底应力、应变的演变曲线. 可以看出, 应变实测值为负 值, 应力实测值为正值, 表明STR19内部深度为 $12 \mathrm{~cm}$ 处 的沥青层层底横向水平应变 $\varepsilon_{x}$ 、纵向水平应变 $\varepsilon_{y}$ 均为 压应变, 竖向应力 $\sigma_{z}$ 为压应力. 还可以看出, 三年间, 该 位置处的应力、应变以年为周期呈现显著的交替波动 变化，每一年的变化规律都极为相似，即冬季低温时， 沥青层层底的应力、应变数值最小; 之后, 数值逐渐增
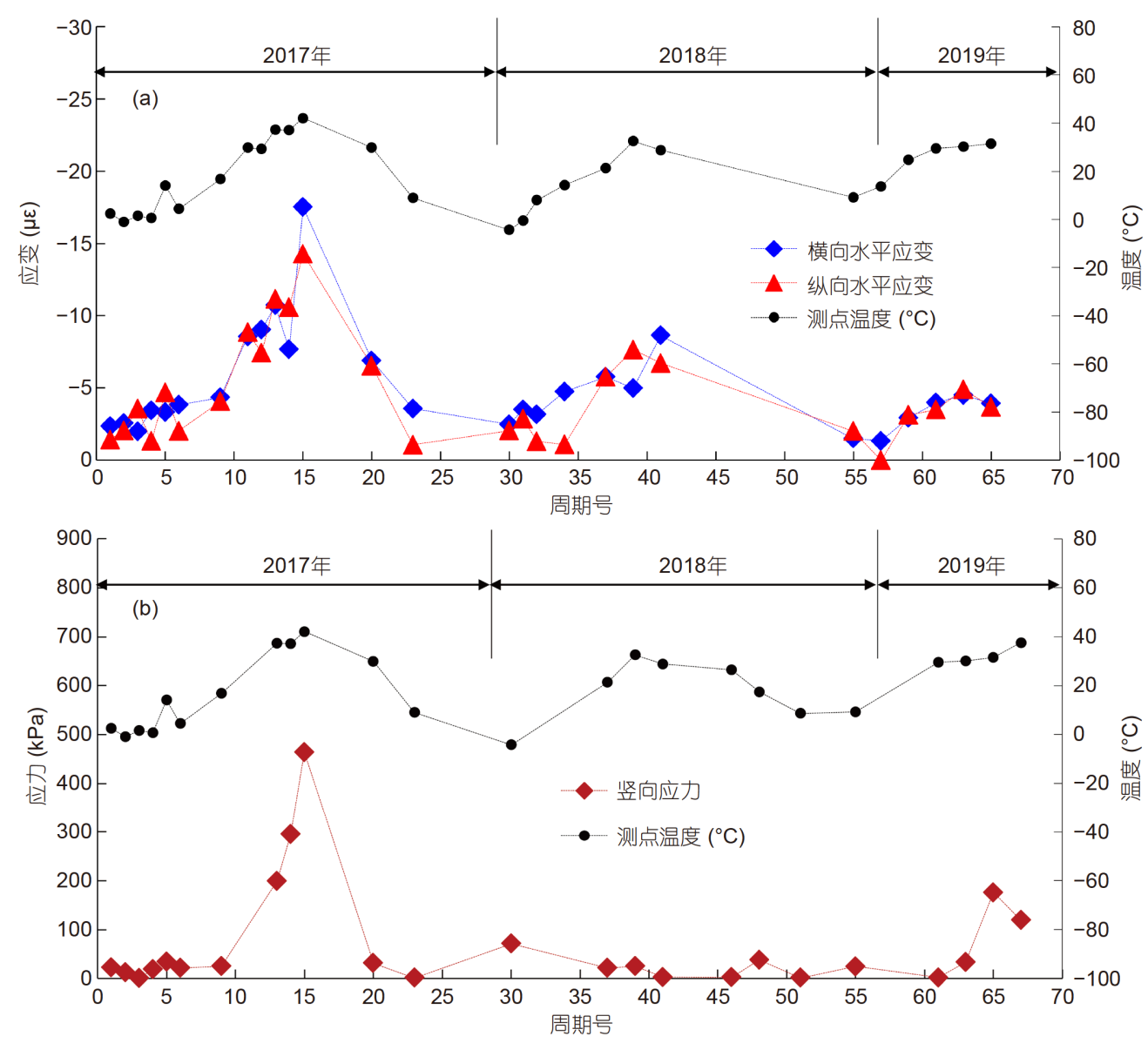

图 4 (网络版彩色)沥青路面年周期内力学响应. (a) 应变; (b) 应力

Figure 4 (Color online) Mechanical response of asphalt pavement structure in a year. (a) Strain; (b) stress 
大, 直至夏季高温时达到最大; 然后, 数值逐渐变小, 到 冬季以后, 应力、应变又减小至很低的水平. 这是由于, 路面结构内部的应力、应变受温度的影响较大，在年 周期内, 受季节更替影响, 结构内部温度不断变化, 导 致应力、应变以年为周期出现交替变化.

\section{2 温度对力学响应的影响}

\subsection{1 温度对力学响应数值的影响}

为了进一步研究力学响应数值与温度的相关关系, 从图4中提取 STR19内部深度为 $12 \mathrm{~cm}$ 处温度、沥青层 层底应力、应变, 绘制温度与应变、温度与应力的关 系曲线, 如图5所示. 可以看出, 随着温度升高, STR19 内部深度为 $12 \mathrm{~cm}$ 处沥青层层底的应力、应变响应数 值均逐渐增大. 这是因为, 沥青混凝土是一种温度敏感 性材料, 随着温度变化, 其黏弹性力学性质和路用性能 会出现显著变化, 导致沥青混凝土在路面结构中的力 学响应状态发生一定改变. 在温度较低的冬季, 沥青混 凝土的力学性质表现为弹性体, 材料很硬、劲度模量 大、更接近于板体，路面结构内部的应力、应变数值 较小. 在温度较高的夏季, 沥青混凝土的力学性质表现 为黏性体, 材料很软、劲度模量小、更接近于黏流体, 路面结构内部的应力、应变数值较大.
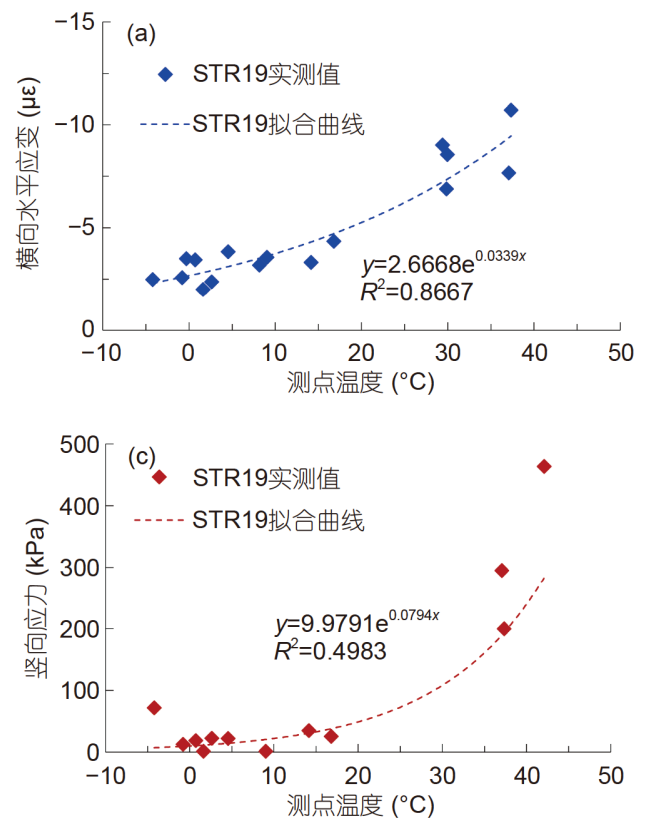

从图5(a)和(b)可以看出, STR19内部深度为 $12 \mathrm{~cm}$ 处沥青层层底应变与温度之间具有较好的相关性. 由 于沥青混合料具有明显的温度依赖性，不同温度下沥 青混凝土材料层的应变响应差别较大, 为了对比不同 路面结构形式、不同累计轴次下的结构响应行为, 需 要建立沥青材料层的实测应变数值与温度的函数关系, 通过温度修正后统一对比条件. 观察图5(a)和(b)中散点 的变化趋势可以看出, 应变与温度之间呈现单调增加 的变化趋势, 故选择多种具有单调关系的函数进行拟 合. 结果发现, 采用式(1)中的指数函数关系拟合精度 最高, 决定系数 $R^{2}$ 可达 0.86 以上，具有较高的可靠性. 因此, 当需要剥离温度对应变响应的影响时, 可以采用 式(1)所建立的应变-温度函数关系式对应变响应进行 温度修正, 统一在某一基准温度下进行相互比较:

$y=a \mathrm{e}^{b x}$,

式中, $y$ 为应变 (应力), $x$ 为温度, $a 、 b$ 为回归参数.

从图 5(c)可以看出, STR19内部深度为 $12 \mathrm{~cm}$ 处沥 青层层底应力与温度之间采用式(1)中的指数函数关系 拟合效果较差, 决定系数 $R^{2}$ 不足 0.5 . 为了寻找应力与温 度之间的合理关系, 提高拟合精度, 我们尝试了多种模 型, 最终发现采用Boltzmann函数进行拟合效果最好,
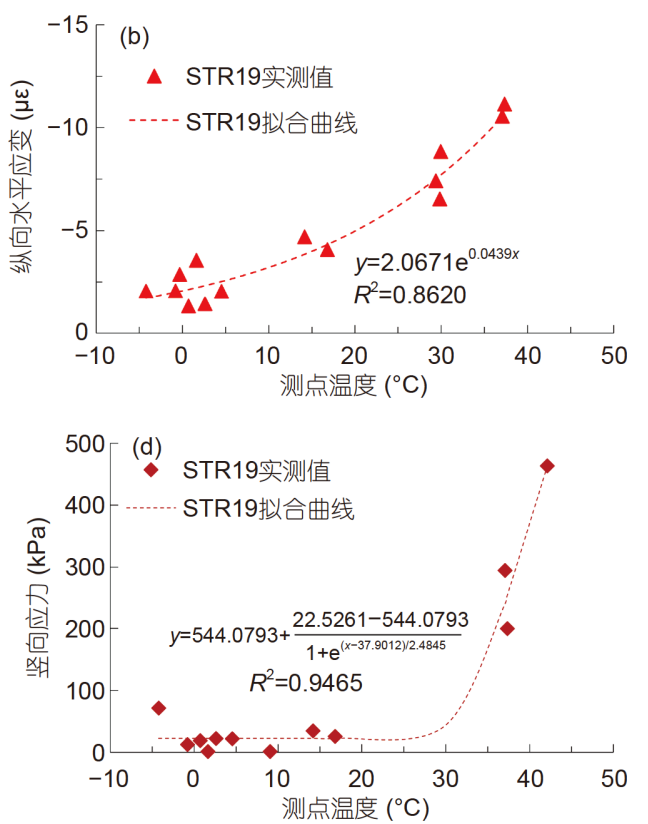

图 5 (网络版彩色)温度与应力、应变的关系 $\left(h=12 \mathrm{~cm}\right.$ ). (a) 横向水平应变 $\varepsilon_{x} ;$ (b) 纵向水平应变 $\varepsilon_{y ;}$ (c) 坚向应力 $\sigma_{z}$ (指数函数); (d) 坚向应力 $\sigma_{z}$ (Boltzmann函数)

Figure 5 (Color online) Relationship between temperature and strain \& stress $(h=12 \mathrm{~cm})$. (a) Transverse horizontal strain $\varepsilon_{x}$; (b) vertical horizontal strain $\varepsilon_{y}$; (c) vertical stress $\sigma_{z}$ (exponential function); (d) vertical stress $\sigma_{z}$ (Boltzmann function) 
见式(2). 经回归分析后, 竖向应力与温度之间的相关系 数能够显著提高, 决定系数 $R^{2}$ 可达到 0.94 以上, 如 图5(d)所示，模型精度得到了明显改善. 因此，对于坚 向应力而言, 应采用Boltzmann函数模型进行温度修正, 不宜采用单调指数函数. 这种现象说明, 沥青路面在服 役过程中, 在一定温度范围内, 温度的变化对应力的影 响较为显著, 但当温度低于某一数值, 或高于某一数值 时, 应力变化较为缓慢, 即温度对应力响应的影响存在 一个敏感区间.

$y=b+\frac{a-b}{1+\mathrm{e}^{(x-c) / d}}$,

式中, $y$ 为应力, $x$ 为温度, $a 、 b 、 c 、 d$ 为回归参数.

\subsection{2 温度对力学响应方向的影响}

从对图 4 和 5 的分析可知, 对于STR19内部深度为 $12 \mathrm{~cm}$ 处的应力、应变而言, 温度只是单调地影响着它 们数值的大小, 并没有改变其受力方向, 这与此前国内 外学者们的研究结论相似 ${ }^{[16 \sim 18]}$. 图4和5 是以STR19内 部深度为 $12 \mathrm{~cm}$ 处的受力状态为研究对象, 这种现象是 否适合于结构内部的其他层位, 我们不得而知. 为了研 究温度对其他结构层位力学响应方向的影响, 我们仍 选择STR19结构，持续观测2017 2019年间路面结构内 部深度为 $24 、 36 、 48 \mathrm{~cm}$ 位置处沥青材料层层底横向
水平应变 $\varepsilon_{x}$ 的响应数值, 绘制温度与应变的相关关系曲 线, 如图6所示. 可以看出, 随着温度升高, 路面结构内 部深度为 $24 \mathrm{~cm}$ 位置处横向水平应变 $\varepsilon_{x}$ 的应变响应方向 表现为受压一一受拉——受压的交替变化，即当结构 内部温度较低和较高时应变响应为压应变, 而当温度 处于中间段时为拉应变，存在两个拉伸-压缩转换点和 一条应变 0 值线. 这一现象与 2.2 .1 节中被大家普遍接受 的温度只是引起力学响应数值增减的变化趋势完全不 同, 表明对于沥青材料层较厚的全厚式路面而言, 沥青 路面在服役期间，环境温度变化会引起某一深度位置 处力学响应方向的改变，会出现由压缩到拉伸或由拉 伸到压缩的转换. 由此可以推断，在这个深度位置处， 随着温度的交替变化, 力学响应方向也会交替变化, 从 而引起该位置处出现温度疲劳隐患，比其他位置处的 受力更为不利. 路面结构内部深度为 $36 、 48 \mathrm{~cm}$ 位置处 的应变响应规律与2.2.1节中相同, 温度只是单调地影 响着它们数值的大小, 并没有改变其受力方向.

\section{3 荷载水平对力学响应的影响}

图7为某年夏季和冬季观测周期内，RIOHTrack主 试验结构STR1内部深度为 $12 \mathrm{~cm}$ 处沥青层层底竖向应 力 $\sigma_{z}$ 、纵向水平应变 $\varepsilon_{y}$ 与 FWD荷载水平之间的关系曲
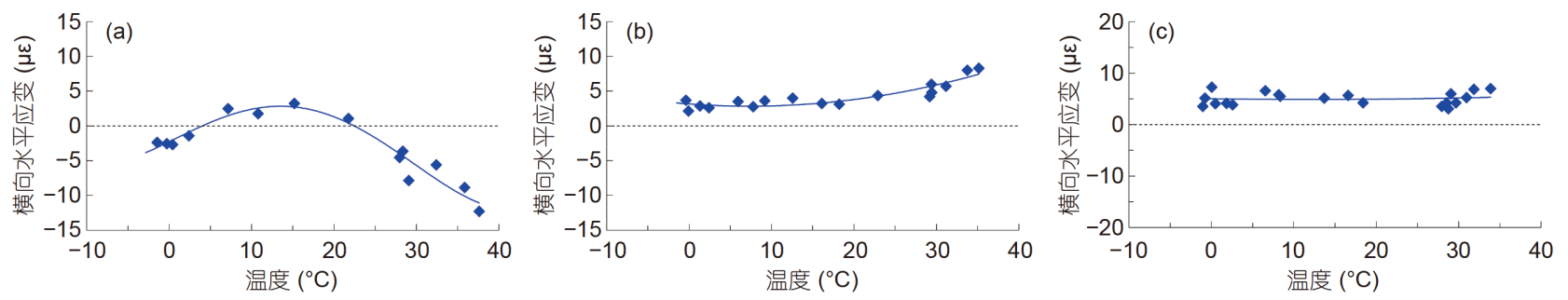

图 6 (网络版彩色)温度与横向水平应变关系. (a) $h=24 \mathrm{~cm}$; (b) $h=36 \mathrm{~cm}$; (c) $h=48 \mathrm{~cm}$

Figure 6 (Color online) Relationship between temperature and transverse horizontal strain. (a) $h=24 \mathrm{~cm}$; (b) $h=36 \mathrm{~cm}$; (c) $h=48 \mathrm{~cm}$
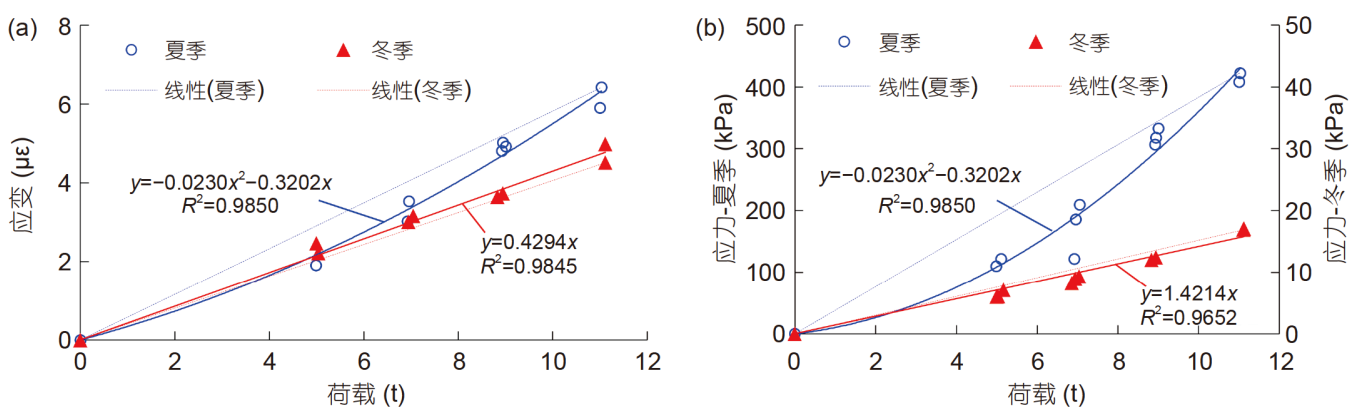

图 7 (网络版彩色)应变/应力与荷载关系(STR1). (a) 应变 $\varepsilon_{y}$ 与荷载关系 $(\mathrm{STR} 1) ;(\mathrm{b})$ 应力 $\sigma_{z}$ 与荷载关系 $(\mathrm{STR} 1)$

Figure 7 (Color online) Relationship between strain/stress and load (STR1). (a) Relationship between load and strain $\varepsilon_{y}$ (STR1); (b) relationship between load and stress $\sigma_{z}$ (STR1) 
线. 可以看出, STR1内部深度为 $12 \mathrm{~cm}$ 处沥青层层底竖 向应力 $\sigma_{z}$ 、纵向水平应变 $\varepsilon_{y}$ 随着 $\mathrm{FWD}$ 荷载水平的增加 而显著增大, 并表现出明显的非线性变化趋势, 路面结 构内部的力学响应具有荷载依赖性. 特别是在温度较 高的夏季且FWD荷载较重时，这种非线性变化趋势更 加明显, 应力-荷载、应变-荷载的相关关系可以采用二 次曲线函数进行表达. 沥青路面的荷载依赖性主要受 路面材料非线性性质的影响, 在温度较低的冬季, 路面 材料硬、劲度模量大, 服从线弹性本构关系, 力学响应 遵循线弹性力学问题. 在温度较高的夏季, 路面材料 软、劲度模量小, 服从非线性本构关系, 力学响应遵循 非线性力学问题, 此时, 如果荷载较重, 力学响应会表 现出材料非线性和几何非线性现象.

\section{4 力学响应沿深度的分布特征}

图8为某年春季、夏季、冬季观测周期内, $\mathrm{RIOH}-$ Track主试验结构STR1和STR19内部各层层底横向水 平应变 $\varepsilon_{x}$ 、纵向水平应变 $\varepsilon_{y}$ 随深度的变化曲线. 可以看 出, 无论哪个季节, STR1内部深度为 $12 、 32 \mathrm{~cm}$ 处路面 结构层层底均为压应变，而52、72、92 cm处路面结构 层层底均为拉应变, 最大拉应变点出现在 $52 \mathrm{~cm}$ 深度处, 且不随季节改变. 还可以看出, 无论哪个季节, STR19内 部深度为 $12 \mathrm{~cm}$ 处路面结构层层底均为压应变，36、 48、 $68 \mathrm{~cm}$ 处路面结构层层底均为拉应变, 而 $24 \mathrm{~cm}$ 处
路面结构层层底应变会随着温度的变化而出现压缩一 拉伸转换, 最大拉应变点出现在 $48 \mathrm{~cm}$ 深度处, 且不随 季节改变. 出现压缩-拉伸转换的深度位于 $24 \sim 36 \mathrm{~cm}$ 之 间，随着温度升高，压缩-拉伸转换的深度会渐渐背离 路表而向下移动. 这是由于, 当温度较低时, 沥青混凝 土结构层更接近于板体，外力荷载可以在沥青混凝土 结构层内进行消散，不会再向下传递; 当温度较高时, 沥青混凝土结构层板体性消失, 接近于黏流态体, 此时 外力荷载无法在上部结构进行消散, 只能向下部传递.

此外, 由于STR19基层材料使用了低标号沥青混凝 土，其在 $20^{\circ} \mathrm{C} 、 5 \mathrm{~Hz}$ 时的动态模量可达 $17218 \mathrm{MPa}$ ，比 STR1结构中使用的水泥稳定碎石规范推荐弹性模量 中值 $11500 \mathrm{MPa}$ (乘以模量调整系数 0.5 后)高出约 $5700 \mathrm{MPa}$ ，在相同荷载作用下产生的应变更小，导致 STR1结构中水稳碎石基层层底应变数值大于STR19结 构中沥青层层底应变数值. 需要说明的是, 本文关于应 力、应变响应的观测结果截至2019年第三季度，随着 后续累计标准轴载作用次数的增加, 这一现象可能会 发生改变, 需要通过持续跟踪观测来不断更新我们的 认识

\section{3 结语}

路面实际力学响应与力学分析理论越接近, 越能 更好地指导沥青路面分析与设计. 因此, 获取路面服役
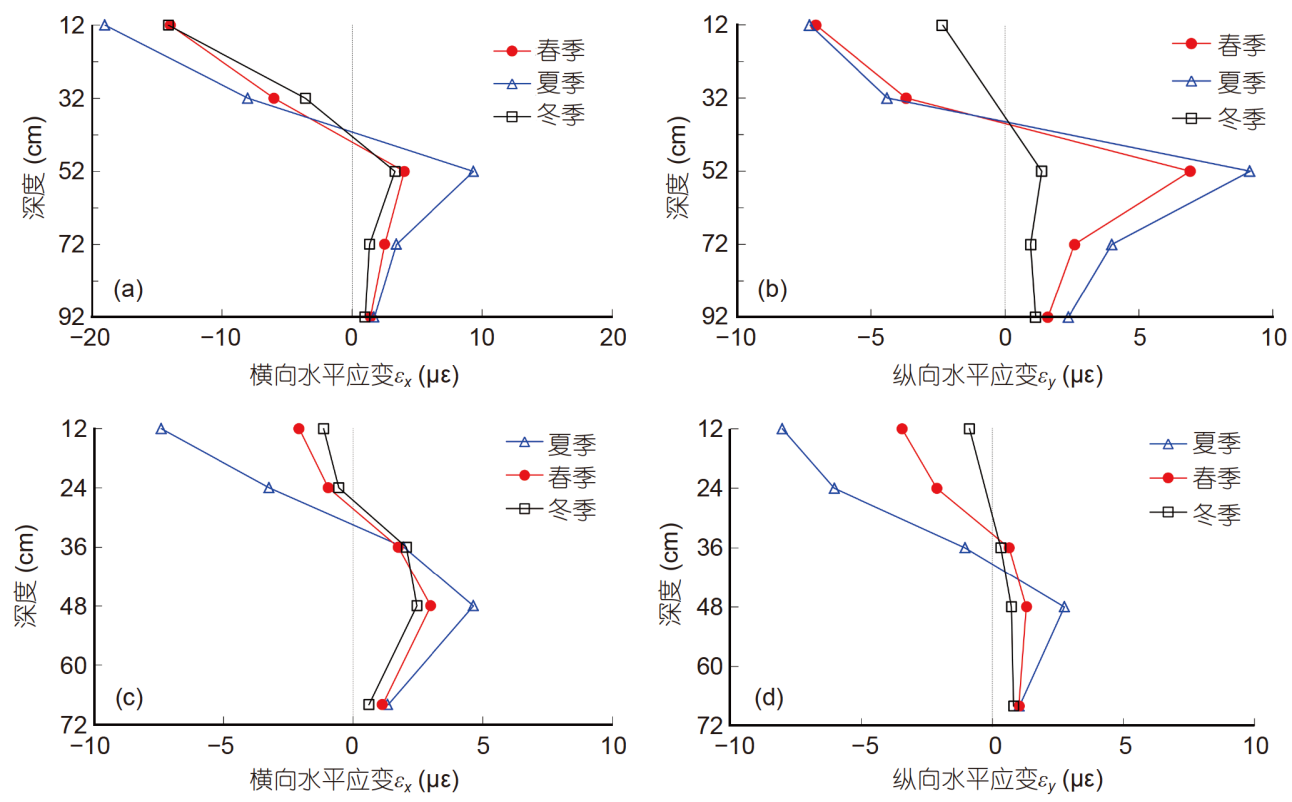

图 8 (网络版彩色)深度与应变关系. (a) $\varepsilon_{x}(\mathrm{STR} 1) ;(\mathrm{b}) \varepsilon_{y}(\mathrm{STR} 1) ;$ (c) $\varepsilon_{x}(\mathrm{STR} 19)$; (d) $\varepsilon_{y}$ (STR19)

Figure 8 (Color online) Relationship between depth and strain. (a) $\varepsilon_{x}$ (STR1); (b) $\varepsilon_{y}$ (STR1); (c) $\varepsilon_{x}$ (STR19); (d) $\varepsilon_{y}$ (STR19) 
过程中的结构内部力学响应特征, 不仅是沥青路面结 构设计的基本问题之一，也是保证路面结构分析方法 科学合理的关键. 为了揭示实体路面结构的力学响应 特征, 健全沥青路面结构力学体系, 依托我国足尺路面 试验环道RIOHTrack, 研究了温度、荷载等外部因素对 沥青路面结构内部力学响应特征的影响规律, 获得了 建立沥青路面计算体系和分析理论所需的真实路面结 构力学响应，完善了此前几十年间因无法开展足尺试 验而缺少系统性路面结构力学响应观测试验数据的不 足, 为路面设计和分析提供了基础数据.

本文研究发现，沥青路面结构内部的力学响应具 有温度依赖性和荷载依赖性，且随着温度、荷载的变 化呈现显著的非线性变化特征，而现行多数沥青路面 设计方法所使用的线弹性层状体系理论, 由于不能客 观描述励青路面结构服役过程中的非线性服役行为和 实际力学响应, 存在明显的局限性, 因此在建立新一代 沥青路面设计方法时，必须考虑非线性力学理论进行 计算, 方可保证路面力学分析的合理性. 此外, 对温度 依赖性的研究发现, 温度变化除引起力学响应数值的 变化以外, 还会引起某些位置处力学响应方向的改变, 会出现压缩到拉伸或者拉伸到压缩状态的转换，这与 被大家普遍接受的温度仅引起力学响应数值单调增减 的认识完全不同. 据此推断，在结构内部某些位置处,
随着温度的交替变化，由于力学响应方向也会交替变 化, 会导致这些位置出现温度疲劳问题, 受力更为不 利. 通过本研究, 还可以得出以下主要结论:

（1）沥青路面结构内部的应力、应变等力学响应 会以年为周期呈现显著的交替波动变化：冬季低温时 沥青层层底的应力、应变数值最小, 随着温度升高, 数 值逐渐增大, 直至夏季高温时达到最大, 之后数值变小, 到冬季以后又减小至很低的水平.

（2）对于路面结构内部大多数位置而言, 温度只是 单调地影响力学响应的数值大小, 并不改变方向, 应变 与温度关系可以采用指数函数描述, 应力与温度关系 曲线可以采用Boltzmann函数描述，且决定系数 $R^{2}$ 可达 到 0.94 以上.

（3）对于全厚式路面结构内部的沥青混凝土结构 层而言, 温度会改变力学响应的方向, 应变与温度的关 系曲线存在拉伸-压缩转换点和应变 0 值线. 在深度方向 上, 出现压缩-拉伸转换的深度位于 $24 \sim 36 \mathrm{~cm}$ 之间, 随着 温度升高，压缩-拉伸转换的深度会渐渐背离路表而向 下移动.

（4）沥青层层底应力、应变响应随着荷载水平增 加而显著增大, 并表现为明显的非线性变化趋势, 路面 结构内部的力学响应具有荷载依赖性, 尤其是在高 温、重载时非线性现象更加明显.

\section{参考文献}

1 Zhou X Y. Structure response and non-linear analysis of asphalt pavement based on full-scale loop test (in Chinese). Doctor Dissertation. Harbin: Harbin Institute of Technology, 2018 [周兴业. 基于足尺环道试验的沥青路面结构响应及其非线性分析. 博士学位论文. 哈尔滨: 哈尔滨工业 大学, 2018]

2 Deusen D V, Investigator P. 2013 MnRoad Construction Report. Minnesota Department of Transportation, 2014

3 Dai S T, Van Deusen D A. Digital Signal Processing for MnRoad Offline Data. Minnesota Department of Transportation, 1996

4 Epps J A, Hand A, Seeds S, et al. Recommended Performance-related Specification for Hot-mix Asphalt Construction: Results of the WesTrack Project. Transportation Research Board, 2002

5 Tsai B W, Harvey J T, Monismith C L. WesTrack fatigue performance prediction using Miner's law. Transp Res Record, 2002, 1809: 137-147

6 Timm D H, Priest A L. Dynamic Pavement Response Data Collection and Processing at the NCAT Test Track. National Center for Asphalt Technology, 2004

7 Timm D H, Voller V R, Lee E, et al. Calcool: A multi-layer asphalt pavement cooling tool for temperature prediction during construction. Int J Pavement Eng, 2001, 2: 169-185

8 Yuan Y J, Zhou J C. Summary of the results of the first phase of NCAT ring road test in USA (in Chinese). J China Foreign Highw, 2005, 25: 109112 [袁迎捷, 周进川. 美国NCAT环道试验第一阶段成果综述. 中外公路, 2005, 25: 109-112]

9 Deng T, Zhou W. Summary of the results of the third phase of NCAT ring road test in USA (in Chinese). J China Foreign Highw, 2013, 33: 284287 [队泰, 周文. 美国NCAT环道试验第三阶段成果综述. 中外公路, 2013, 33: 284-287]

10 Dong Z J, Liu H, Tan Y Q, et al. Field measurement of three-direction strain response of asphalt pavement (in Chinese). J South China Univ Technol (Nat Sci Ed), 2009, 37: 50-55 [董泽蛟, 柳浩, 谭忆秋, 等. 沥青路面三向应变响应现场实测研究. 华南理工大学学报(自然科学版), 2009, 37: 50-55]

11 Dong Z J, Li S L, Wen J Y, et al. Real-time temperature measurement of asphalt pavement based on fiber bragg grating measuring technology (in 
Chinese). J Traff Transp Eng, 2014, 14: 1-6 [董泽蛟, 李生龙, 温佳宇, 等. 基于光纤光栅测试技术的沥青路面温度场实测. 交通运输工程学报, 2014, 14: 1-6]

12 Zhou X Y, Wang X D, Su B. Study on mechanical response test method for real pavement structure model (in Chinese). J Highw Transp Res Dev, 2017, 34: 23-29 [周兴业, 王旭东, 苏波. 路面实体结构模型力学响应试验方法研究. 公路交通科技, 2017, 34: 23-29]

13 Yao Z K. Structural Design of Asphalt Pavements (in Chinese). Beijing: China Communications Press, 2011 [姚祖康. 沥青路面结构设计. 北京: 人民交通出版社, 2011]

14 Wang X D. Design of pavement structure and material for full-scale test track (in Chinese). J Highw Transp Res Dev, 2017, 34: 30-37 [王旭东. 足 尺路面试验环道路面结构与材料设计. 公路交通科技, 2017, 34: 30-37]

15 Wang X D, Zhou X Y. Equivalent mechanical method of asphalt pavement structure based on material nonlinearity (in Chinese). China J Highw Transp, 2019, 32: 25-34 [王旭东, 周兴业. 基于材料非线性的沥青路面结构当量力学分析方法. 中国公路学报, 2019, 32: 25-34]

16 Willis J R, Timm D H. Field-Based Strain Thresholds for Flexible Perpetual Pavement Design. National Center for Asphalt Technology, 2009

17 Dong Z J, Tan Y Q. Dynamic Response of Asphalt Pavement (in Chinese). Beijing: Science Press, 2015 [董泽蛟, 谭忆秋. 沥青路面动力响应研 究. 北京: 科学出版社, 2015]

18 West R C, Timm D H, Powell R B, et al. Phase V (2012-2014) NCAT Test Track Findings. National Center for Asphalt Technology, 2018 


\title{
Characteristics and analysis of the mechanical response inside the structure of asphalt pavement
}

\author{
Xudong Wang, Xingye Zhou*, Wei Guan \& Qian Xiao \\ Research Institute of Highway Ministry of Transport, Beijing 100088, China \\ * Corresponding author, E-mail: zhouxingye1982@163.com
}

Determining whether structural analysis method can objectively describe the real service status of pavements is the main issue in the design of asphalt pavements. Given the complexity and variety of pavement materials, the responses of pavement structures under vehicle load and environmental conditions exhibit clear nonlinear characteristics. Obtaining the structural mechanical response characteristics in the course of pavement service is not only the solution to one of the basic issues in the structural design of asphalt pavements, but also the key to ensure the scientific and reasonable analysis of pavement structures. To reveal the structural mechanical response characteristics and change the law of asphalt pavements and provide reliable data for the development of structural design methods that are suitable for the national conditions and highway construction characteristics in China, continuous follow-up observations of the mechanical responses of asphalt pavement structures, such as stress and strain, are conducted using RIOHTrack. The actual service environment and mechanical response law of asphalt pavement structures are obtained using sensor testing technology. The influence law of external factors, such as temperature and load, on the mechanical response behavior is analyzed and the temperature and load dependences of the true mechanical response are revealed. Results show that the structural mechanical response of asphalt pavements exhibits significant temperature and load dependence and that a nonlinear relationship exists between temperature and load. To ensure the rationality of pavement analysis, nonlinear mechanics theory requires consideration in the structural calculations. The stress and strain of asphalt pavements display alternating fluctuations in the annual cycle; the smallest and largest values of the stress and strain at the bottom of the asphalt layer are observed during winter and summer, respectively. For semi-rigid base asphalt pavements, the temperature monotonically affects the value of the mechanical response of the asphalt surface layer and does not change the direction of force. An exponential function can describe the relationship of strain and temperature, whereas the Boltzmann function can describe that of stress and temperature; the decision coefficient $R^{2}$ for both functions exceeds 0.94 and therefore indicates good correlation. For fullthick asphalt pavements, the temperature change causes an increase or decrease in the mechanical response values, and a change in direction, that is, compression state and tensile state can switch to each other. And the relationship curve between strain and temperature shows a pull conversion point and a zero strain line. In the depth direction, the compression-tensile conversion occurs between $24-36 \mathrm{~cm}$, and as the temperature increases, the position of the compression-tensile conversion gradually moves down from the surface. The strain response significantly increases with the increase in load level and shows a clear trend of nonlinear change, especially at high temperature and overload. The actual structural mechanical response of the pavement needed to establish the asphalt pavement calculation system and analysis theory is obtained, which addresses the lack of systematic surface structural mechanical response observation test data due to the inability to perform full-scale tests before and provides the basic data for pavement design and analysis. Results can offer theoretical support for polishing the design and analysis methods for asphalt pavements.

mechanical response, asphalt pavement, stress, strain, pavement design

doi: $10.1360 /$ TB-2020-0233 